\title{
Inhibition Mechanism of Urease by Au(III) Compounds Unveiled by X-ray Diffraction Analysis
}

\author{
Luca Mazzei, ${ }^{\dagger}$ Margot N. Wenzel, ${ }^{\ddagger}$ Michele Cianci, ${ }^{\S}$ Marta Palombo, ${ }^{\dagger}$ Angela Casini, ${ }^{*}, \ddagger \odot$ \\ and Stefano Ciurli* ${ }^{\dagger}$ (i)
}
${ }^{\dagger}$ Laboratory of Bioinorganic Chemistry, Department of Pharmacy and Biotechnology, University of Bologna, Viale Giuseppe Fanin 40, I-40127 Bologna, Italy
${ }^{\ddagger}$ School of Chemistry, Cardiff University, Main Building, Park Place, CF10 3AT Cardiff, United Kingdom
${ }^{\S}$ Department of Agricultural, Food and Environmental Sciences, Marche Polytechnic University, Via Brecce Bianche, I-60131 Ancona, Italy

Supporting Information

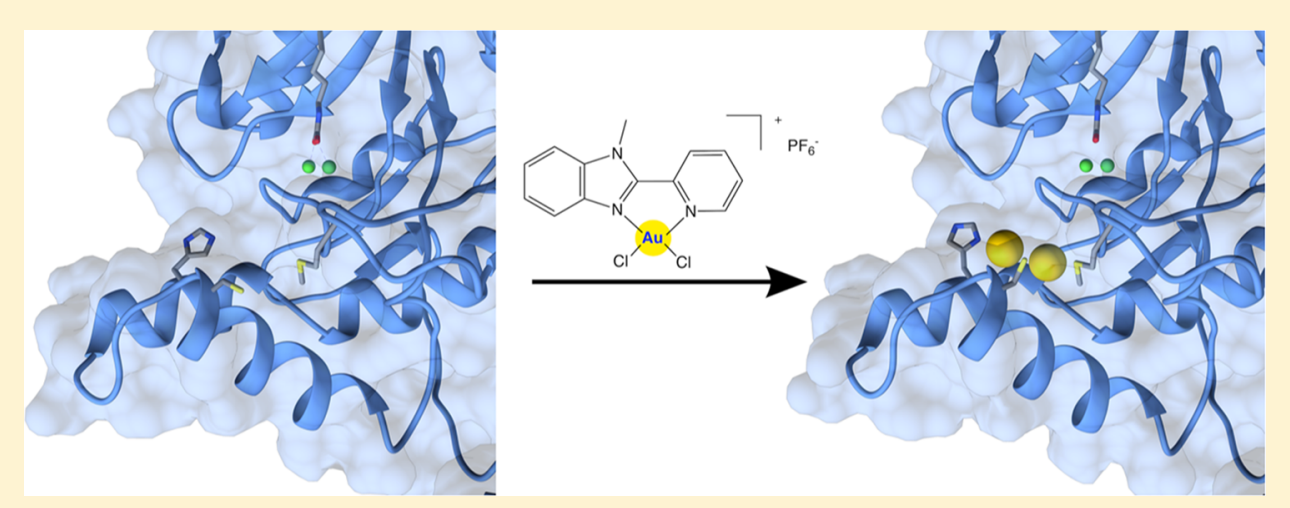

ABSTRACT: The nickel-dependent enzyme urease is a virulence factor for a large number of critical human pathogens, making this enzyme a potential target of therapeutics for the treatment of resistant bacterial infections. In the search for novel urease inhibitors, five selected coordination and organometallic $\mathrm{Au}(\mathrm{III})$ compounds containing $\mathrm{N}^{\wedge} \mathrm{N}$ or $\mathrm{C}^{\wedge} \mathrm{N}$ and $\mathrm{C}^{\wedge} \mathrm{N}^{\wedge} \mathrm{N}$ ligands were tested for their inhibitory effects against Canavalia ensiformis (jack bean) urease. The results showed potent inhibition effects with $\mathrm{IC}_{50}$ values in the nanomolar range. The 2.14 Å resolution crystal structure of Sporosarcina pasteurii urease inhibited by the most effective $\mathrm{Au}(\mathrm{III})$ compound $\left[\mathrm{Au}(\mathrm{PbImMe}) \mathrm{Cl}_{2}\right] \mathrm{PF}_{6}(\mathrm{PbImMe}=1$-methyl-2-(pyridin-2-yl)-benzimidazole $)$ reveals the presence of two $\mathrm{Au}$ ions bound to the conserved triad $\alpha \mathrm{Cys} 322 / \alpha \mathrm{His} 323 / \alpha \mathrm{Met} 367$. The binding of the Au ions to these residues blocks the movement of a flap, located at the edge of the active site channel and essential for enzyme catalysis, completely obliterating the catalytic activity of urease. Overall, the obtained results constitute the basis for the design of new gold complexes as selective urease inhibitors with future antibacterial applications.

KEYWORDS: urease, nickel, gold compounds, X-ray structure, ureolytic pathogens, metal-based drugs

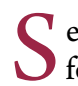
everal metals and metal-based compounds have been used for centuries as anti-infective agents on a simple empirical basis with some appreciable results. For instance, gold cyanide was proposed by Koch as an antitubercular agent in the pioneering times of modern pharmacology. ${ }^{1}$ Since then, remarkable progress has been made on the development of gold complexes as therapeutic agents, starting from the antiarthritis agent auranofin (AF) [2,3,4,6-tetra-o-acetyl-Lthio- $\beta$-D-glucopyranosato- $S$-(triethyl-phosphine)Au(I)]. Recently, this drug is receiving increasing attention for its potential to be repurposed as anticancer, antiparasitic, and antibacterial agent, ${ }^{2-4}$ leading to the development of novel gold-based antibacterial agents acting as specific inhibitors of several important enzymes. ${ }^{4-12}$

For example, a family of $\mathrm{Au}(\mathrm{I})$-based phosphine complexes were tested and compared with AF toward a representative panel of pathogens that included Gram-positive, Gramnegative, and Candida strains ${ }^{13}$ and showed activity on Gram-positive strains. More recently, organometallic $\mathrm{Au}(\mathrm{I})$ $\mathrm{N}$-heterocyclic carbene (NHC) complexes were reported as effective antibacterial agents toward Gram-positive bacteria. ${ }^{9,14-16}$ Despite an increasing number of studies, the precise mechanism of the antimicrobial action of $\mathrm{Au}(\mathrm{I})$ complexes and their biomolecular targets is unknown. Due to the reported inhibition of the mammalian selenoenzyme thioredoxin reductase (TrxR) by $\mathrm{AF}$ and $\mathrm{Au}(\mathrm{I})$ NHCs complexes, with

Special Issue: Highlighting Medicinal Chemistry in Italy

Received: November 28, 2018

Accepted: January 4, 2019

Published: January 4, 2019 
formation of a stable $\mathrm{Au}$-selenol adduct at the active site of the protein, ${ }^{17}$ it was hypothesized that this enzyme could also be responsible for the observed antibacterial effects. However, the bacterial TrxRs lack the "aurophilic" selenol active site, ${ }^{18}$ and this may account for the reduced affinity of $\mathrm{Au}(\mathrm{I})$ binding with respect to mammalian TrxRs.

Within this framework, only rare studies on the possible use of $\mathrm{Au}$ (III) complexes as targeted inhibitors of bacterial enzymes have appeared so far. For example, phosphorus dendrimers bearing iminopyridino end groups coordinating to $\mathrm{Au}(\mathrm{III})$ ions were reported to inhibit the growth of both Gram-positive and Gram-negative bacterial strains. ${ }^{19}$ Moreover, moderate antibacterial activity of $\mathrm{Au}$ (III) complexes with different L-histidine-containing dipeptides was described, ${ }^{20}$ but no mechanistic investigation was conducted to rationalize the observed biological effects. In general, $\mathrm{Au}$ (III) complexes have less affinity and selectivity for TrxR binding, ${ }^{21}$ while they appear to target different types of mammalian proteins, including zinc finger proteins, ${ }^{22,23}$ water/glycerol channels, ${ }^{24,25}$ the proteasome, ${ }^{26}$ and phosphatases, ${ }^{27}$ among others.

An emerging target for bacterial infections is urease (urea amidohydrolase, E.C. 3.5.1.5), a nickel-dependent enzyme found in a large variety of organisms ${ }^{28-32}$ and featuring a bimetallic $\mathrm{Ni}(\mathrm{II})$-containing reaction site. ${ }^{29,30,32}$ Urease is involved in the global nitrogen cycle, catalyzing the rapid hydrolytic decomposition of urea to eventually yield ammonia and carbonate, ${ }^{33,34}$ consequently causing a $\mathrm{pH}$ increase that has negative effects on both agriculture ${ }^{35}$ and human health. ${ }^{36}$ For instance, ten of the twelve antibiotic-resistant priority pathogens listed in 2017 by the World Health Organization (WHO) are ureolytic bacteria for which urease is a virulence factor. ${ }^{37}$ Moreover, mixed species infections are more difficult to treat because of an increased tolerance to antimicrobials. ${ }^{36}$ The general high significance given by the WHO to the antimicrobial-resistance priority, supported by the Global Antimicrobial Resistance Surveillance System (GLASS), ${ }^{38}$ raises urease to the attention of researchers as a target to develop new drugs for the treatment of important bacterial infections acting as a threat to public health worldwide. Moreover, the very high structure conservation of ureases from plants and bacteria warrants the possibility to extend the results obtained in the pharmaceutical and medical applications to the agro-environmental field, for which an excessive urease activity also represents a negative aspect. ${ }^{28-32}$

A large number of urease inhibitors such as $\beta$-mercaptoethanol, ${ }^{39}$ phosphate, $^{40}$ sulfite, $^{41}$ and fluoride, ${ }^{42}$ as well as hydroxamic, ${ }^{43}$ citric, $^{44}$ and boric ${ }^{45}$ acids, 1,4-benzoquinone ${ }^{46}$ and catechol, ${ }^{47}$ diamido-phosphate, and monoamido-thiophosphate originating, respectively, by urease-catalyzed hydrolysis of phenylphosphorodiamidate (PPD $)^{48}$ or $N$-(n-butyl)thiophosphoric triamide (NBPT) ${ }^{49}$ have been studied, and the structural details of their modes of action have been elucidated. Additionally, metal ions such as $\mathrm{Co}(\mathrm{II}), \mathrm{Ni}(\mathrm{II})$, $\mathrm{Cu}(\mathrm{II}), \mathrm{Zn}(\mathrm{II}), \mathrm{Cd}(\mathrm{II}), \mathrm{Pb}(\mathrm{II}), \mathrm{Hg}(\mathrm{II})$, and $\mathrm{Ag}(\mathrm{I})$ are also good urease inhibitors. ${ }^{50-52}$ Within this context, the efficacy of $\mathrm{Ag}(\mathrm{I})$ as a urease inactivator has been recently rationalized by the structural determination of its adduct with Sporosarcina pasteurii (S. pasteurii) urease (SPU). ${ }^{53} \mathrm{Ag}(\mathrm{I})$ deactivates urease by forming a dinuclear cluster of two $\mathrm{Ag}(\mathrm{I})$ ions bound to the largely conserved triad $\alpha$ Cys322/ $\alpha$ His $323 / \alpha \operatorname{Met} 367$, thus blocking the movement of a structural motif (mobile flap), essential for urease activity, consequently inhibiting the catalytic activity of the enzyme. Remarkably, no Au compound has ever been tested as urease inhibitor so far.

We report here on a urease inhibition activity screening of selected $\mathrm{Au}(\mathrm{III})$ complexes with bidentate $\mathrm{N}$-donor ligands or cyclometalated $\mathrm{C}^{\wedge} \mathrm{N}$ and $\mathrm{C}^{\wedge} \mathrm{N}^{\wedge} \mathrm{N}$ scaffolds (compounds $\mathbf{1 - 5}$, Figure 1). In detail, two coordination complexes with

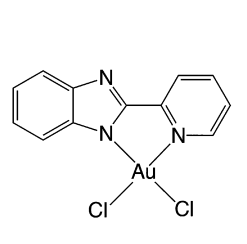

1
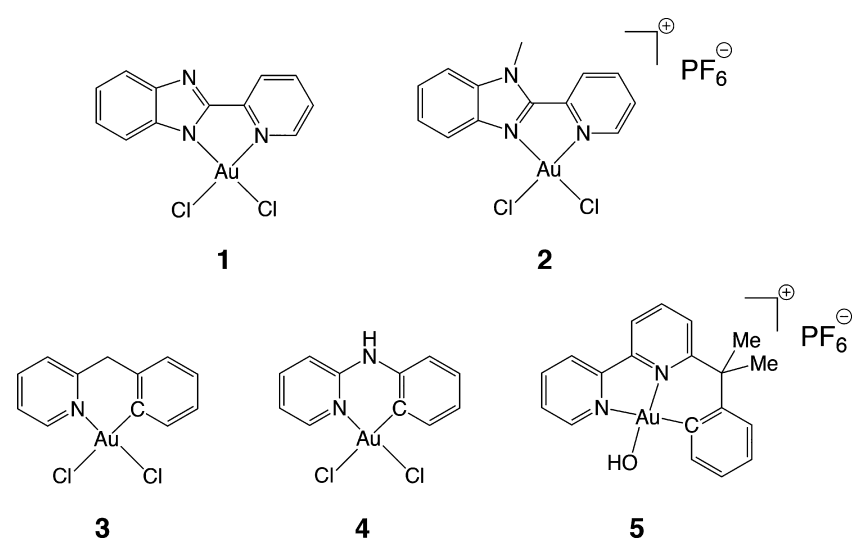

Figure 1. Schematic structures of $\mathrm{Au}(\mathrm{III})$ complexes tested for urease inhibition.

(pyridyl)benzimidazole type ligands, $\left[\mathrm{Au}(\mathrm{PbIm}) \mathrm{Cl}_{2}\right]$ (1) $(\mathrm{PbIm}=2-(\text { pyridin-2-yl }) \text {-benzimidazole })^{54}$ and $[\mathrm{Au}-$ $\left.(\mathrm{PbImMe}) \mathrm{Cl}_{2}\right] \mathrm{PF}_{6}$ (2) (PbImMe = 1-methyl-2-(pyridin-2yl)-benzimidazole), ${ }^{24}$ were selected. Moreover, three organometallic $\mathrm{Au}(\mathrm{III})$ compounds, featuring the $\mathrm{C}^{\wedge} \mathrm{N}$ cyclometalated 2-benzylpyridine $\left(\mathrm{py}^{\mathrm{b}}-\mathrm{H}\right)$ ligand $(3)^{55}$ and $N$-phenylpyridin-2-amine $\left(\right.$ phepy $\left.^{\mathrm{a}}\right)$ ligand $(4),{ }^{56}$ as well as the tridentate $\mathrm{C}^{\wedge} \mathrm{N}^{\wedge} \mathrm{N}$ ligand 6-(1,1-dimethylbenzyl)-2,2'-bipyridine (bipy $^{\mathrm{dmb}}$ ) (5), 57 were also examined. The compounds were synthesized according to previously reported procedures. $^{24,54-57}$ The $\mathrm{Au}(\mathrm{III})$ compounds were tested for their inhibitory effects against Canavalia ensiformis (jack bean) urease (JBU) in vitro, and the structure of the adduct obtained upon incubation of compound $\mathbf{2}$ with SPU was determined by X-ray diffraction crystallography. Model coordinates and structure factors were deposited in the Protein Data Bank (PDB) under the accession code 6I9Y.

The efficiency of urease inhibition by compounds $\mathbf{1 - 5}$ was tested by incubating JBU for $1 \mathrm{~h}$ in the presence of increasing concentrations of the different compounds, in order for the enzyme-inhibitor complex to reach a steady-state condition. Subsequently, the activity of urease was determined (see Supporting Information for experimental details). Plots of the reaction rate after incubation, normalized against the reaction rate of the untreated enzyme, as a function of inhibitor concentration, show a sigmoidal distribution (Figure 1-SI). A fit of the data to the canonical equation to obtain the inhibitor concentrations bringing about $50 \%$ inactivation of the enzyme $\left(\mathrm{IC}_{50}\right)$ yielded similar values for compounds $\mathbf{1 - 5}$, in the lownanomolar concentration range (Table 1 ). The most potent inhibitor is the cationic coordination complex 2 , while the bidentate neutral $\mathrm{N}^{\wedge} \mathrm{N}$ compound $\mathbf{1}$ and the cyclometalated $\mathrm{C}^{\wedge} \mathrm{N}$ derivatives 3 and 4 are ca. 2-fold less active. This observation suggests that noncovalent gold complex-urease adduct formation, involving electrostatic interactions between the two partners, may be instrumental to facilitate $\mathrm{Au}(\mathrm{III})$ coordinative binding. ${ }^{58}$ In line with previous studies on the reactivity of cyclometalated complexes with proteins, ${ }^{59}$ the 
Table 1. Values of $\mathrm{IC}_{50}$ for the Inhibition of Jack Bean Urease (JBU) by Compounds $1-5$ in Figure 1

\begin{tabular}{ccc} 
compound & type of ligand & $\mathrm{IC}_{50}(\mathrm{nM})$ \\
$\mathbf{1}$ & $\mathrm{N}^{\wedge} \mathrm{N}$ & $18 \pm 1$ \\
$\mathbf{2}$ & $\mathrm{N}^{\wedge} \mathrm{N}$ & $9.0 \pm 0.2$ \\
3 & $\mathrm{C}^{\wedge} \mathrm{N}$ & $14.9 \pm 0.5$ \\
4 & $\mathrm{C}^{\wedge} \mathrm{N}$ & $16.4 \pm 0.5$ \\
5 & $\mathrm{C}^{\wedge} \mathrm{N}^{\wedge} \mathrm{N}$ & $31 \pm 1$ \\
\hline
\end{tabular}

$\mathrm{Au}(\mathrm{III}) \mathrm{C}^{\wedge} \mathrm{N}^{\wedge} \mathrm{N}$ complex $\mathbf{5}$ is the least efficient of the series. Notably, the urease inhibition strength of the $\mathrm{Au}(\mathrm{III})$ compounds is comparable to that observed for other metal ions (namely, $\mathrm{Hg}(\mathrm{II}), \mathrm{Ag}(\mathrm{I})$, and $\mathrm{Cu}(\mathrm{II}))$ and $2-3$ orders of magnitude greater than in the case of $\mathrm{Zn}$ (II), $\mathrm{Cd}(\mathrm{II}), \mathrm{Ni}(\mathrm{II})$, $\mathrm{Pb}(\mathrm{II})$, and $\mathrm{Co}(\mathrm{II}) .^{50-52}$ However, the advantage of using coordination or organometallic compounds allows the finetuning of the properties of the respective $\mathrm{Au}(\mathrm{III})$ complexes, reduces their speciation in aqueous solution, and allows for further optimization of the selectivity properties for a certain target.

The X-ray crystal structure of SPU cocrystallized in the presence of the best urease inhibitor, specifically the cationic $\mathrm{Au}(\mathrm{III})$ compound 2 (PDB code 6I9Y, see Supporting Information for experimental details; data collection, processing and refinement statistics for Au-inhibited SPU are provided in Table 1-SI) shows the well-described heteropolymeric nature of $S$. pasteurii urease, consisting of an $(\alpha \beta \gamma)_{3}$ quaternary structure. The similarity of the protein scaffold with respect to native urease (PDB code $4 \mathrm{CEU})^{42}$ is confirmed by the RMSD between their $\mathrm{C} \alpha$ atoms $(0.29,0.25$, and $0.20 \AA$ for the $\alpha, \beta$, and $\gamma$ subunits, respectively). A more detailed analysis of the $\mathrm{C} \alpha$ RMSD (Figure 2-SI) reveals that the $\beta$ and $\gamma$ subunits show a largely invariant backbone with respect to that of the native enzyme, whereas three portions of the $\alpha$ subunit, containing the Ni-bound active-site, are affected by significantly larger displacements: (i) a region including residues 390-400, located on a surface patch showing a large conformational variability among the SPU structures determined so far, with RMSD values up to ca. $0.9 \AA$, (ii) a region including residues 310-340, which corresponds to the mobile helix-turn-helix motif (mobile flap) responsible for the substrate access into the active site of urease, with RMSD up to ca. $1.4 \AA$, and (iii) the region including residues 548-555, which forms a solvent exposed loop at the C-terminal portion of the $\alpha$ subunit, with RMSD up to ca. $1.2 \AA$.

The overall framework of the Ni-containing active site region of the refined model is highly conserved with respect to the native enzyme, ${ }^{42}$ as revealed by the well-defined electron density represented in Figure 2.

The two $\mathrm{Ni}(\mathrm{II})$ ions, $3.6 \AA$ apart, are bridged by the carboxylate group of the carbamylated $\alpha$ Lys $220 *$ residue, which is bound to $\mathrm{Ni}(1)$ and $\mathrm{Ni}(2)$ by $\mathrm{O} \theta 1$ and $\mathrm{O} \theta 2$, respectively. $\mathrm{Ni}(1)$ is additionally coordinated by $\alpha \mathrm{His} 249 \mathrm{~N} \delta$ and by $\alpha \mathrm{His} 275 \mathrm{~N} \varepsilon$, whereas $\mathrm{Ni}(2)$ is further bound to $\alpha \mathrm{His} 137 \mathrm{~N} \varepsilon, \alpha \mathrm{His} 139 \mathrm{~N} \varepsilon$, and $\alpha \mathrm{Asp} 363 \mathrm{O} \delta 1$. The tetrahedral cluster of four water molecules in the vicinity of the $\mathrm{Ni}$ (II) ions that, in the native urease, are substituted by substrate urea during the enzyme catalytic cycle, are also not perturbed in the presence of the inhibitor. The distances and angles around the $\mathrm{Ni}(\mathrm{II})$ ions in the SPU inhibited by compound $\mathbf{2}$ are largely indistinguishable from those observed in native and $\mathrm{Ag}(\mathrm{I})$ inactivated SPU structures ${ }^{53}$ (Table 2-SI).

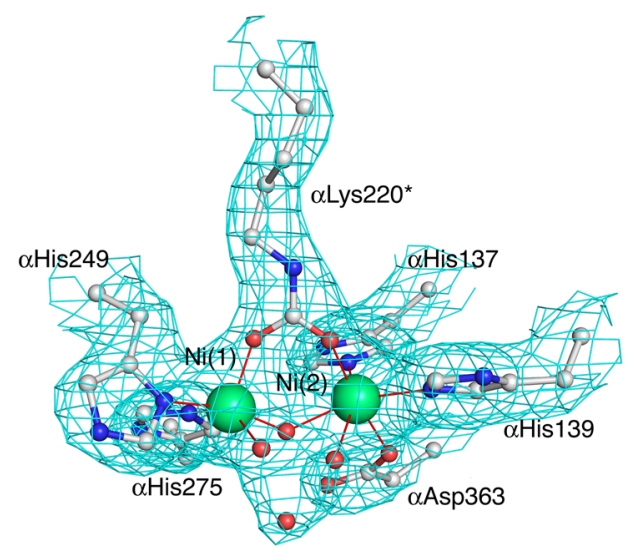

Figure 2. Atomic model of the active site of SPU inhibited in the presence of compound 2 . The nickel coordination environment is shown superimposed on the final $2 F_{\mathrm{o}}-F_{\mathrm{c}}$ electron density map contoured at $1 \sigma$ (cyan). Carbon, nitrogen, oxygen, and nickel atoms are light gray, blue, red, and green, respectively.

The unbiased omit electron density map reveals two additional spherical electron densities located in the vicinity of the mobile flap, around the $\alpha \mathrm{Cys} 322$ thiol, the $\alpha$ His 323 imidazole, and the $\alpha$ Met367 thioether functionalities (Figure $3 \mathrm{~A})$. The strong anomalous difference Fourier electron density maps associated with those $2 F_{\mathrm{o}}-F_{\mathrm{c}}$ electron densities

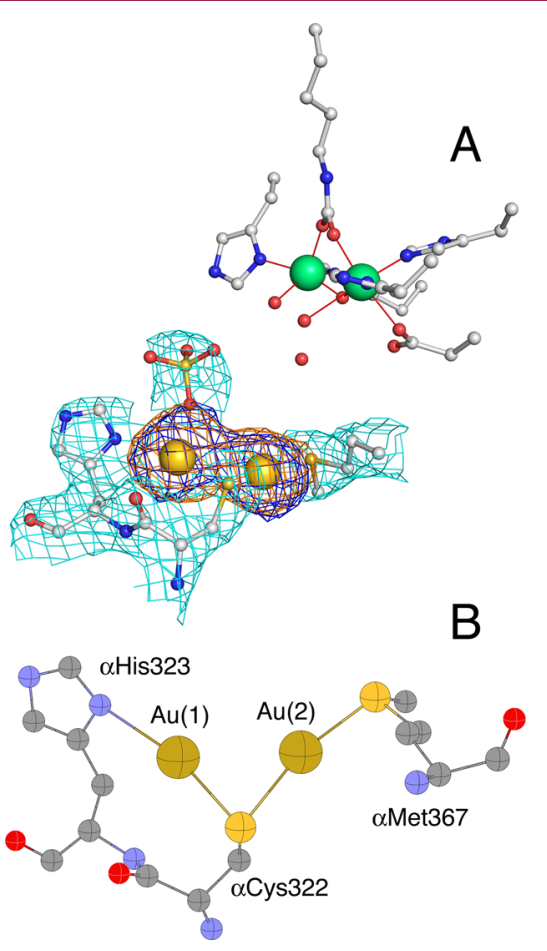

Figure 3. (A) Atomic model of the $\mathrm{Ni}(\mathrm{II})$-containing active site of SPU inhibited in the presence of compound 2, together with the region affected by $\mathrm{Au}(\mathrm{I})$ binding (PDB code 6I9Y). The model for the latter region is shown superimposed onto the final $2 F_{o}-F_{c}$ electron density map contoured at $1 \sigma$ (cyan). The unbiased $F_{o}-F_{c}$ omit map is shown contoured at $3.0 \sigma$ (orange). The anomalous difference electron density map contoured at $3.0 \sigma$ is also shown (dark blue). (B) Coordination environment of the $\mathrm{Au}(\mathrm{I})$ dinuclear cluster in the structure of SPU inhibited in the presence of compound 2 . The occupancy of the gold atoms is 0.85 . Carbon, nitrogen, oxygen, nickel, and gold atoms are light gray, blue, red, green, and gold, respectively. 
suggested the presence of two Au atoms in this region (Figure $3 \mathrm{~A})$. The coordination environment around the two $\mathrm{Au}$ atoms bound to the His-Cys-Met triad (Figure 3A,B) involves $\alpha \mathrm{His} 323 \mathrm{~N} \delta$ and to $\alpha \mathrm{Cys} 322 \mathrm{~S} \gamma$ for $\mathrm{Au}(1)$ and $\alpha \mathrm{Cys} 322 \mathrm{~S} \gamma$ and $\alpha \operatorname{Met} 367 \mathrm{~S} \delta$ for $\mathrm{Au}(2)$ (Figure 3B; all distances and angles around the $\mathrm{Au}$ atoms are reported in Table 3-SI). The two $\mathrm{Au}$ ions are bridged by Cys322 S $\gamma$ and are separated by $3.27 \AA$.

The quasi-linear geometric arrangement of the ligands is compatible with the presence of two $\mathrm{Au}(\mathrm{I})$ ions. This conclusion is also supported by previously reported electrochemical studies of compound 2, which features a reduction potential for the $\mathrm{Au}$ III/I reduction process $E_{\text {red }}=-0.33 \mathrm{~V}$, demonstrating the possibility for the complex to undergo reduction in biological environment. The short $\mathrm{Au} \cdots \mathrm{Au}$ distance $(3.27 \AA)$, the small $\mathrm{Au}(1)-\alpha \mathrm{Cys} 322 \mathrm{~S} \gamma-\mathrm{Au}(2)$ angle $\left(73.2^{\circ}\right)$, and the slight distortion of the $\alpha$ His 323 $\mathrm{N} \delta-\mathrm{Au}(1)-\alpha \operatorname{Cys} 322 \mathrm{~S} \gamma$ and $\alpha \mathrm{Cys} 322 \mathrm{~S} \gamma-\mathrm{Au}(2)-\alpha \operatorname{Met} 367$ S $\delta$ angles $\left(166.4^{\circ}\right.$ and $159.5^{\circ}$, respectively), caused by a bowing effect of the two $\mathrm{Au}$ atoms toward each other, are strong indications of the presence of an aurophilic interaction between the two $\mathrm{Au}(\mathrm{I})$ ions. $^{60}$

A third electron density was observed close to $\alpha$ Cys555 S $\gamma$ in the C-terminal portion of the $\alpha$ chain, also featuring a strong anomalous signal suggesting the presence of a third $\mathrm{Au}$ atom in that region. This $\mathrm{Au}(3)$ atom resides in a position $25-27 \AA$ distant from the $\mathrm{Ni}$ (II) ions in the active site, with no evident influence on the catalytic mechanism. The oxidation state of this atom cannot be established with certainty based on the coordination geometry, because no electron density clearly attributable to ligands other than the side chain thiol sulfur atom can be observed, even though the presence of additional ligands, such as disordered water molecules, cannot be excluded.

The protein backbone of urease in the vicinity of the active site flap is strongly affected by the presence of the two Au ions, compared to the structure of the native enzyme (Figure 4), in a similar manner to that of $\mathrm{Ag}(\mathrm{I})$-inhibited urease. ${ }^{53}$ Specifically, the region around the Au-binding $\alpha \mathrm{Cys} 322$ and $\alpha \mathrm{His} 323$, residues belonging to the mobile flap, features RMSD values for the backbone $\mathrm{C} \alpha$ atoms with respect to the corresponding atoms of native SPU that are significantly larger than the average for the unbound enzyme (Figure 2-SI). The thiolate $S \gamma$ atom of $\alpha \mathrm{Cys} 322$ and the imidazole ring of $\alpha$ His 323 are shifted by ca. 2.3 and $1.2 \AA$, respectively, in order to coordinate the two $\mathrm{Au}$ ions (Figure 4). The $\mathrm{Au}(2)$ ion also provides the establishment of a covalent bridge between the mobile flap, with $\alpha$ Cys 322 and $\alpha$ His323, and the more rigid portion of the protein that hosts $\alpha$ Met367, with its $\mathrm{S} \delta$ shifted by $0.3 \AA$ (Figure 3).

Overall, we have shown here that the $\mathrm{Au}$ (III) complexes 15 are able to potently inhibit urease. Moreover, we have also structurally characterized by X-ray diffraction, for the first time, the adduct of $\mathrm{Au}$ ions with essential residues in the vicinity of the urease active site, elucidating the mechanism of inhibition at a molecular level. In the case of coordination compounds with bidentate $\mathrm{N}^{\wedge} \mathrm{N}$ ligands, the binding directly involves residues likely to impair the enzymatic mechanism via alterations of the overall protein structure. The lack of the organic ligand in the crystal structure of SPU inhibited by compound 2, leaving only two naked $\mathrm{Au}$ ions bound to the conserved Cys-His-Met triad, suggests the presence of several successive steps of ligand substitutions and metal reduction leading to the final structure observed in the solid state. As

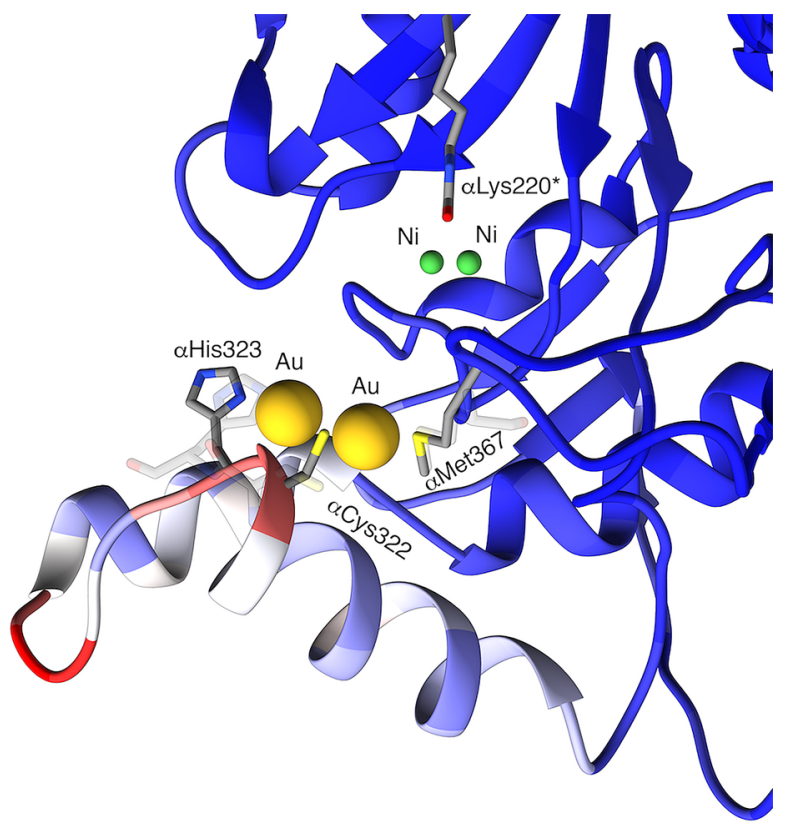

Figure 4. Ribbon diagram of a close-up of the structure of SPU inhibited in the presence of compound 2 (PDB code 6I9Y) in the vicinity of the active site region, showing the position of the mobile flap; the ribbon is colored according to the RMSD calculated with respect to the native enzyme (PDB code 4CEU) (red, RMSD > 1; pink, $0.5<$ RMSD $<1$; white, RMSD $=0.5$; blue, RMSD $<0.5)$. The $\mathrm{Ni}$ and $\mathrm{Au}$ atoms are shown as green and gold spheres, respectively. The transparent atoms show the conformation of the side chain of the residues $\alpha$ Cys322, $\alpha$ His323, and $\alpha \operatorname{Met} 367$ in the native enzyme.

observed for previously reported $\mathrm{Au}(\mathrm{III}) /$ protein adducts, this type of compound favors exchange of the original ligands and further possible reduction to $\mathrm{Au}(\mathrm{I})$ species. ${ }^{61-63}$

It is worth mentioning that so far only a few X-rays structures of gold complexes $(\mathrm{Au}(\mathrm{I})$ and $\mathrm{Au}(\mathrm{III})$ ) with proteins have been reported, ${ }^{64}$ where these metal ions bind to Cys, ${ }^{65,66}$ Lys, $^{67}$ or His residues. ${ }^{68}$ Further studies are necessary to validate the binding mode of the cyclometalated $\mathrm{Au}$ (III) complexes to urease. In this case, retention of the cyclometalated ligands may be envisaged upon protein adduct formation, ${ }^{23}$ which would be essential to design ureasetargeted inhibitors. Finally, our results hold promise for the screening of the antibacterial properties of $\mathrm{Au}(\mathrm{III})$ complexes in ureolytic microorganisms, including Mycobacterium tuberculosis, Helicobacter pylori, Yersinia pestis, and Cryptococcus neoformans.

\section{ASSOCIATED CONTENT}

\section{Supporting Information}

The Supporting Information is available free of charge on the ACS Publications website at DOI: 10.1021/acsmedchemlett.8b00585.

Experimental details of the kinetics measurements of JBU inhibition by compounds $\mathbf{1 - 5}$, the crystallization of the adduct between SPU and compound 5, and the Xray diffraction data collection, processing and refinement, final refinement statistics, and geometric parameters for $\mathrm{Ni}$ and $\mathrm{Au}$ coordination environments (PDF) 


\section{AUTHOR INFORMATION}

\section{Corresponding Authors}

*S.C. E-mail: stefano.ciurli@unibo.it.

*A.C. E-mail: casinia@cardiff.ac.uk.

ORCID $\odot$

Angela Casini: 0000-0003-1599-9542

Stefano Ciurli: 0000-0001-9557-926X

\section{Author Contributions}

The manuscript was written through contributions of all authors.

\section{Funding}

L.M. is supported by a fellowship from the University of Bologna and by CIRMMP (Consorzio Interuniversitario di Risonanze Magnetiche di Metallo-Proteine). M.P. is a Ph.D. student supported by the University of Bologna. The University of Bologna and Cardiff University are acknowledged for funding and infrastructure support.

Notes

The authors declare no competing financial interest.

\section{ACKNOWLEDGMENTS}

$\mathrm{X}$-ray diffraction data were collected under the beam time award number MX-1949 from the European Synchrotron Radiation Source (ESRF, Grenoble, France).

\section{REFERENCES}

(1) Koch, R. Über bakteriologische Forschung; Robert Koch-Institut, 2010.

(2) Sannella, A. R.; Casini, A.; Gabbiani, C.; Messori, L.; Bilia, A. R.; Vincieri, F. F.; Majori, G.; Severini, C. New uses for old drugs. Auranofin, a clinically established antiarthritic metallodrug, exhibits potent antimalarial effects in vitro: Mechanistic and pharmacological implications. FEBS Lett. 2008, 582, 844-847.

(3) Roder, C.; Thomson, M. J. Auranofin: repurposing an old drug for a golden new age. Drugs $R \& D$ 2015, 15, 13-20.

(4) Aguinagalde, L.; Diez-Martinez, R.; Yuste, J.; Royo, I.; Gil, C.; Lasa, I.; Martin-Fontecha, M.; Marin-Ramos, N. I.; Ardanuy, C.; Linares, J.; Garcia, P.; Garcia, E.; Sanchez-Puelles, J. M. Auranofin efficacy against MDR Streptococcus pneumoniae and Staphylococcus aureus infections. J. Antimicrob. Chemother. 2015, 70, 2608-2617.

(5) Madeira, J. M.; Gibson, D. L.; Kean, W. F.; Klegeris, A. The biological activity of auranofin: implications for novel treatment of diseases. Inflammopharmacology 2012, 20, 297-306.

(6) Cassetta, M. I.; Marzo, T.; Fallani, S.; Novelli, A.; Messori, L. Drug repositioning: auranofin as a prospective antimicrobial agent for the treatment of severe staphylococcal infections. BioMetals 2014, 27, 787-791.

(7) Hokai, Y.; Jurkowicz, B.; Fernandez-Gallardo, J.; Zakirkhodjaev, N.; Sanau, M.; Muth, T. R.; Contel, M. Auranofin and related heterometallic gold(I)-thiolates as potent inhibitors of methicillinresistant Staphylococcus aureus bacterial strains. J. Inorg. Biochem. 2014, 138, 81-88.

(8) Hikisz, P.; Szczupak, L.; Koceva-Chyla, A.; Gu Spiel, A.; Oehninger, L.; Ott, I.; Therrien, B.; Solecka, J.; Kowalski, K. Anticancer and Antibacterial Activity Studies of Gold(I)-Alkynyl Chromones. Molecules 2015, 20, 19699-19718.

(9) Owings, J. P.; McNair, N. N.; Mui, Y. F.; Gustafsson, T. N.; Holmgren, A.; Contel, M.; Goldberg, J. B.; Mead, J. R. Auranofin and $\mathrm{N}$-heterocyclic carbene gold-analogs are potent inhibitors of the bacteria Helicobacter pylori. FEMS Microbiol Lett. 2016, 363, fnw148.

(10) Torres, N. S.; Abercrombie, J. J.; Srinivasan, A.; Lopez-Ribot, J. L.; Ramasubramanian, A. K.; Leung, K. P. Screening a commercial library of pharmacologically active small molecules against Staphylococcus aureus Biofilms. Antimicrob. Agents Chemother. 2016, 60, $5663-5672$
(11) AbdelKhalek, A.; Abutaleb, N. S.; Elmagarmid, K. A.; Seleem, M. N. Repurposing auranofin as an intestinal decolonizing agent for vancomycin-resistant enterococci. Sci. Rep. 2018, 8, 8353.

(12) Mizdal, C. R.; Stefanello, S. T.; Nogara, P. A.; Antunes Soares, F. A.; de Lourenco Marques, L.; de Campos, M. M. A. Molecular docking, and anti-biofilm activity of gold-complexed sulfonamides on Pseudomonas aeruginosa. Microb. Pathog. 2018, 125, 393-400.

(13) Marzo, T.; Cirri, D.; Pollini, S.; Prato, M.; Fallani, S.; Cassetta, M. I.; Novelli, A.; Rossolini, G. M.; Messori, L. Auranofin and its analogues show potent antimicrobial activity covering multi-resistant pathogens: structure-activity relationships. ChemMedChem 2018, 13, 2448.

(14) Fernandez, G. A.; Vela Gurovic, M. S.; Olivera, N. L.; Chopa, A. B.; Silbestri, G. F. Antibacterial properties of water-soluble gold(I) $\mathrm{N}$-heterocyclic carbene complexes. J. Inorg. Biochem. 2014, 135, 5457.

(15) Schmidt, C.; Karge, B.; Misgeld, R.; Prokop, A.; Bronstrup, M.; Ott, I. Biscarbene gold(I) complexes: structure-activity-relationships regarding antibacterial effects, cytotoxicity, TrxR inhibition and cellular bioavailability. MedChemComm 2017, 8, 1681-1689.

(16) Velle, A.; Maguire, R.; Kavanagh, K.; Sanz Miguel, P. J.; Montagner, D. Steroid-Au(I)-NHC Complexes: synthesis and antibacterial activity. ChemMedChem 2017, 12, 841-844.

(17) Bindoli, A.; Rigobello, M. P.; Scutari, G.; Gabbiani, C.; Casini, A.; Messori, L. Thioredoxin reductase: A target for gold compounds acting as potential anticancer drugs. Coord. Chem. Rev. 2009, 253, $1692-1707$

(18) Lennon, B. W.; Williams, C. H., Jr.; Ludwig, M. L. Crystal structure of reduced thioredoxin reductase from Escherichia coli: structural flexibility in the isoalloxazine ring of the flavin adenine dinucleotide cofactor. Protein Sci. 1999, 8, 2366-2379.

(19) Mignani, S. M.; El Brahmi, N.; El Kazzouli, S.; Laurent, R.; Ladeira, S.; Caminade, A. M.; Pedziwiatr-Werbicka, E.; Szewczyk, E. M.; Bryszewska, M.; Bousmina, M. M.; Cresteil, T.; Majoral, J. P. Original multivalent gold(III) and dual gold(III)-copper(II) conjugated phosphorus dendrimers as potent antitumoral and antimicrobial agents. Mol. Pharmaceutics 2017, 14, 4087-4097.

(20) Warzajtis, B.; Glisic, B. D.; Savic, N. D.; Pavic, A.; Vojnovic, S.; Veselinovic, A.; Nikodinovic-Runic, J.; Rychlewska, U.; Djuran, M. I. Mononuclear gold(III) complexes with 1-histidine-containing dipeptides: tuning the structural and biological properties by variation of the N-terminal amino acid and counter anion. Dalton Trans 2017, 46, 2594-2608.

(21) Gabbiani, C.; Mastrobuoni, G.; Sorrentino, F.; Dani, B.; Rigobello, M. P.; Bindoli, A.; Cinellu, M. A.; Pieraccini, G.; Messori, L.; Casini, A. Thioredoxin reductase, an emerging target for anticancer metallodrugs. Enzyme inhibition by cytotoxic gold(III) compounds studied with combined mass spectrometry and biochemical assays. MedChem Comm 2011, 2, 50-54.

(22) Jacques, A.; Lebrun, C.; Casini, A.; Kieffer, I.; Proux, O.; Latour, J. M.; Seneque, O. Reactivity of Cys4 zinc finger domains with gold(III) complexes: insights into the formation of "gold fingers". Inorg. Chem. 2015, 54, 4104-4113.

(23) Wenzel, M. N.; Meier-Menches, S. M.; Williams, T. L.; Ramisch, E.; Barone, G.; Casini, A. Selective targeting of PARP-1 zinc finger recognition domains with $\mathrm{Au}(\mathrm{III})$ organometallics. Chem. Commun. (Cambridge, U. K.) 2018, 54, 611-614.

(24) de Almeida, A.; Mosca, A. F.; Wragg, D.; Wenzel, M.; Kavanagh, P.; Barone, G.; Leoni, S.; Soveral, G.; Casini, A. The mechanism of aquaporin inhibition by gold compounds elucidated by biophysical and computational methods. Chem. Commun. (Cambridge, U. K.) 2017, 53, 3830-3833.

(25) Martins, A. P.; Ciancetta, A.; de Almeida, A.; Marrone, A.; Re, N.; Soveral, G.; Casini, A. Aquaporin inhibition by gold(III) compounds: new insights. ChemMedChem 2013, 8, 1086-1092.

(26) Zhang, X.; Frezza, M.; Milacic, V.; Ronconi, L.; Fan, Y.; Bi, C.; Fregona, D.; Dou, Q. P. Inhibition of tumor proteasome activity by gold-dithiocarbamato complexes via both redox-dependent and -independent processes. J. Cell. Biochem. 2010, 109, 162-172. 
(27) Boorsma, C. E.; van der Veen, T. A.; Putri, K. S. S.; de Almeida, A.; Draijer, C.; Mauad, T.; Fejer, G.; Brandsma, C. A.; van den Berge, M.; Bosse, Y.; Sin, D.; Hao, K.; Reithmeier, A.; Andersson, G.; Olinga, P.; Timens, W.; Casini, A.; Melgert, B. N. A potent tartrate resistant acid phosphatase inhibitor to study the function of TRAP in alveolar macrophages. Sci. Rep. 2017, 7, 12570.

(28) Hausinger, R. P. Nickel utilization by microorganisms. Microbiol. Rev. 1987, 51, 22-42.

(29) Maroney, M. J.; Ciurli, S. Nonredox nickel enzymes. Chem. Rev. 2014, 114, 4206-4228.

(30) Mazzei, L.; Musiani, F.; Ciurli, S. Urease. In The Biological Chemistry of Nickel; The Royal Society of Chemistry, 2017; pp 60-97.

(31) Mobley, H. L.; Hausinger, R. P. Microbial ureases: significance, regulation, and molecular characterization. Microbiol. Rev. 1989, 53, $85-108$.

(32) Zambelli, B.; Musiani, F.; Benini, S.; Ciurli, S. Chemistry of $\mathrm{Ni}^{2+}$ in urease: sensing, trafficking, and catalysis. Acc. Chem. Res. 2011, 44, 520-530.

(33) Blakeley, R. L.; Hinds, J. A.; Kunze, H. E.; Webb, E. C.; Zerner, B. Jack bean urease (EC 3.5.1.5). Demonstration of a carbamoyltransfer reaction and inhibition by hydroxamic acids. Biochemistry 1969, 8, 1991-2000.

(34) Dixon, N. E.; Riddles, P. W.; Gazzola, C.; Blakeley, R. L.; Zerner, B. Jack bean urease (EC 3.5.1.5). V. On the mechanism of action of urease on urea, formamide, acetamide, $\mathrm{N}$-methylurea, and related compounds. Can. J. Biochem. 1980, 58, 1335-1344.

(35) Kiss, S.; Simihaian, M. Improving efficiency of urea fertilizers by inhibition of soil urease activity; Kluwer Academic Publishers: Dordrecht, The Netherlands, 2002.

(36) Rutherford, J. C. The emerging role of urease as a general microbial virulence factor. PLoS Pathog. 2014, 10, e1004062.

(37) WHO Global priority list of antibiotic-resistant bacteria to guide research, discovery, and development of new antibiotics; World Health Organization, Geneva, 2017.

(38) WHO Global antimicrobial resistance surveillance system (GLASS) report: early implementation 2016-2017; World Health Organization, Geneva, 2017.

(39) Benini, S.; Rypniewski, W. R.; Wilson, K. S.; Ciurli, S.; Mangani, S. The complex of Bacillus pasteurii urease with bmercaptoethanol from X-ray data at $1.65 \AA$ resolution. JBIC, J. Biol. Inorg. Chem. 1998, 3, 268-273.

(40) Benini, S.; Rypniewski, W. R.; Wilson, K. S.; Ciurli, S.; Mangani, S. Structure-based rationalization of urease inhibition by phosphate: novel insights into the enzyme mechanism. JBIC, J. Biol. Inorg. Chem. 2001, 6, 778-790.

(41) Mazzei, L.; Cianci, M.; Benini, S.; Bertini, L.; Musiani, F.; Ciurli, S. Kinetic and structural studies reveal a unique binding mode of sulfite to the nickel center in urease. J. Inorg. Biochem. 2016, 154, $42-49$.

(42) Benini, S.; Cianci, M.; Mazzei, L.; Ciurli, S. Fluoride inhibition of Sporosarcina pasteurii urease: structure and thermodynamics. JBIC, J. Biol. Inorg. Chem. 2014, 19, 1243-1261.

(43) Benini, S.; Rypniewski, W. R.; Wilson, K. S.; Miletti, S.; Ciurli, S.; Mangani, S. The complex of Bacillus pasteurii urease with acetohydroxamate anion from X-ray data at 1.55 A resolution. JBIC, J. Biol. Inorg. Chem. 2000, 5, 110-118.

(44) Benini, S.; Kosikowska, P.; Cianci, M.; Mazzei, L.; Vara, A. G.; Berlicki, L.; Ciurli, S. The crystal structure of Sporosarcina pasteurii urease in a complex with citrate provides new hints for inhibitor design. JBIC, J. Biol. Inorg. Chem. 2013, 18, 391-399.

(45) Benini, S.; Rypniewski, W. R.; Wilson, K. S.; Mangani, S.; Ciurli, S. Molecular details of urease inhibition by boric acid: insights into the catalytic mechanism. J. Am. Chem. Soc. 2004, 126, 37143715.

(46) Mazzei, L.; Cianci, M.; Musiani, F.; Ciurli, S. Inactivation of urease by 1,4-benzoquinone: chemistry at the protein surface. Dalton Trans 2016, 45, 5455-5459.
(47) Mazzei, L.; Cianci, M.; Musiani, F.; Lente, G.; Palombo, M.; Ciurli, S. Inactivation of urease by catechol: Kinetics and structure. J. Inorg. Biochem. 2017, 166, 182-189.

(48) Benini, S.; Rypniewski, W. R.; Wilson, K. S.; Miletti, S.; Ciurli, S.; Mangani, S. A new proposal for urease mechanism based on the crystal structures of the native and inhibited enzyme from Bacillus pasteurii: why urea hydrolysis costs two nickels. Structure 1999, 7, 205-216.

(49) Mazzei, L.; Cianci, M.; Contaldo, U.; Musiani, F.; Ciurli, S. Urease Inhibition in the presence of $\mathrm{N}$-(n-butyl)thiophosphoric triamide, a suicide substrate: structure and kinetics. Biochemistry 2017, 56, 5391-5404.

(50) Krajewska, B.; Ureases, I. Functional, catalytic and kinetic properties: A review. J. Mol. Catal. B: Enzym. 2009, 59, 9-21.

(51) Krajewska, B. Mono- $(\mathrm{Ag}, \mathrm{Hg})$ and di- $(\mathrm{Cu}, \mathrm{Hg})$ valent metal ions effects on the activity of jack bean urease. Probing the modes of metal binding to the enzyme. J. Enzyme Inhib. Med. Chem. 2008, 23, $535-542$.

(52) Zaborska, W.; Krajewska, B.; Olech, Z. Heavy metal ions inhibition of jack bean urease: potential for rapid contaminant probing. J. Enzyme Inhib. Med. Chem. 2004, 19, 65-69.

(53) Mazzei, L.; Cianci, M.; Gonzalez Vara, A.; Ciurli, S. The structure of urease inactivated by $\mathrm{Ag}(\mathrm{I})$ : a new paradigm for enzyme inhibition by heavy metals. Dalton transactions 2018, 47, 8240-8247.

(54) Serratrice, M.; Cinellu, A.; Maiore, L.; Pilo, M.; Zucca, A.; Gabbiani, C.; Guerri, A.; Landini, I.; Nobili, S.; Mini, E.; Messori, L. Synthesis, structural characterization, solution behavior, and in vitro antiproliferative properties of a series of gold complexes with 2-(2'pyridyl)benzimidazole as ligand: comparisons of gold(III) versus gold(I) and mononuclear versus binuclear derivatives. Inorg. Chem. 2012, 51, 3161-3171.

(55) Cinellu, M. A.; Zucca, A.; Stoccoro, S.; Minghetti, G.; Manassero, M.; Sansoni, M. Synthesis and characterization of gold(III) adducts and cyclometallated derivatives with 6-benzyl- and 6-alkyl-2,2'-bipyridines. J. Chem. Soc., Dalton Trans. 1996, 42174225.

(56) Zhu, Y.; Cameron, B. R.; Mosi, R.; Anastassov, V.; Cox, J.; Qin, L.; Santucci, Z.; Metz, M.; Skerlj, R. T.; Fricker, S. P. Inhibition of the cathepsin cysteine proteases $\mathrm{B}$ and $\mathrm{K}$ by square-planar cycloaurated gold(III) compounds and investigation of their anti-cancer activity. J. Inorg. Biochem. 2011, 105, 754-762.

(57) Cinellu, M. A.; Minghetti, G.; Pinna, M. V.; Stoccoro, S.; Zucca, A.; Manassero, M. Replacement of the chloride ligand in [Au$(\mathrm{C}, \mathrm{N}, \mathrm{N}) \mathrm{Cl}]\left[\mathrm{PF}_{6}\right]$ cyclometallated complexes by $\mathrm{C}, \mathrm{N}, \mathrm{O}$ and $\mathrm{S}$ donor anionic ligands. J. Chem. Soc., Dalton Trans. 1999, 2823-2831.

(58) Graziani, V.; Marrone, A.; Re, N.; Coletti, C.; Platts, J. A.; Casini, A. A multi-level theoretical study to disclose the binding mechanisms of gold(III)-bipyridyl compounds as selective aquaglyceroporin inhibitors. Chem. - Eur. J. 2017, 23, 13802-13813.

(59) Meier, S. M.; Gerner, C.; Keppler, B. K.; Cinellu, M. A.; Casini, A. Mass spectrometry uncovers molecular reactivities of coordination and organometallic gold(III) drug candidates in competitive experiments that correlate with their biological effects. Inorg. Chem. 2016, $55,4248-4259$.

(60) Schmidbaur, H.; Schier, A. A briefing on aurophilicity. Chem. Soc. Rev. 2008, 37, 1931-1951.

(61) Casini, A.; Cinellu, M. A.; Minghetti, G.; Gabbiani, C.; Coronnello, M.; Mini, E.; Messori, L. Structural and solution chemistry, antiproliferative effects, and DNA and protein binding properties of a series of dinuclear gold(III) compounds with bipyridyl ligands. J. Med. Chem. 2006, 49, 5524-5531.

(62) Gabbiani, C.; Casini, A.; Messori, L.; Guerri, A.; Cinellu, M. A.; Minghetti, G.; Corsini, M.; Rosani, C.; Zanello, P.; Arca, M. Structural characterization, solution studies, and DFT calculations on a series of binuclear gold(III) oxo complexes: relationships to biological properties. Inorg. Chem. 2008, 47, 2368-2379.

(63) Cinellu, M. A.; Maiore, L.; Manassero, M.; Casini, A.; Arca, M.; Fiebig, H. H.; Kelter, G.; Michelucci, E.; Pieraccini, G.; Gabbiani, C.; Messori, L. $\left[\mathrm{Au}_{2}(\operatorname{phen}(2 \mathrm{Me}))_{2}(\mu-\mathrm{O})_{2}\right]\left(\mathrm{PF}_{6}\right)_{2}$, a novel dinuclear 
gold(III) complex showing excellent antiproliferative properties. ACS Med. Chem. Lett. 2010, 1, 336-339.

(64) Messori, L.; Merlino, A. Protein metalation by metal-based drugs: X-ray crystallography and mass spectrometry studies. Chem. Commun. (Cambridge, U. K.) 2017, 53, 11622-11633.

(65) Urig, S.; Fritz-Wolf, K.; Reau, R.; Herold-Mende, C.; Toth, K.; Davioud-Charvet, E.; Becker, K. Undressing of phosphine gold(I) complexes as irreversible inhibitors of human disulfide reductases. Angew. Chem., Int. Ed. 2006, 45, 1881-1886.

(66) Parsonage, D.; Sheng, F.; Hirata, K.; Debnath, A.; McKerrow, J. H.; Reed, S. L.; Abagyan, R.; Poole, L. B.; Podust, L. M. X-ray structures of thioredoxin and thioredoxin reductase from Entamoeba histolytica and prevailing hypothesis of the mechanism of Auranofin action. J. Struct. Biol. 2016, 194, 180-190.

(67) Ferraro, G.; Gabbiani, C.; Merlino, A. First crystal structure for a gold carbene-protein adduct. Bioconjugate Chem. 2016, 27, 15841587.

(68) Messori, L.; Scaletti, F.; Massai, L.; Cinellu, M. A.; Gabbiani, C.; Vergara, A.; Merlino, A. The mode of action of anticancer goldbased drugs: a structural perspective. Chem. Commun. (Cambridge, $U$. K.) 2013, 49, 10100-10102. 